\title{
The university, the city and the clown: A theological essay on solidarity, mutuality and prophecy
}

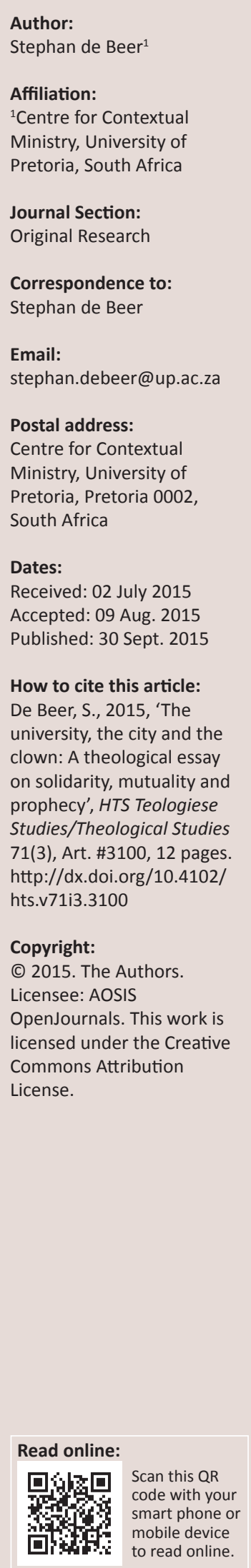

This essay is informed by five different but interrelated conversations all focusing on the relationship between the city and the university. Suggesting the clown as metaphor, I explore the particular role of the activist scholar, and in particular the liberation theologian that is based at the public university, in his or her engagement with the city. Considering the shackles of the city of capital and its twin, the neoliberal university, on the one hand, and the city of vulnerability on the other, I then propose three clown-like postures of solidarity, mutuality and prophecy to resist the shackles of culture and to imagine and embody daring alternatives.

\section{The university, the city and the clown: A theological essay}

How does a public university engage the city in which it is hosted, and in particular the capital city? What is the ethical responsibility of the public university in terms of the city as urban public, but also in terms of the neighbourhoods and inhabitants of the city, and in particular those who are particularly vulnerable and rather unable to access the resources of the university? What is the function of the activist scholar, and more specifically the liberation theologian working at the university? How does the university engage concrete socio-economic-political and existential realities such as homelessness in ways that will contribute to finding just alternatives or solutions in response to precarious living?

These are some of the questions raised in this and other articles in this series under the rubric '(un) shackled'. These articles were informed by five different but somewhat interrelated processes and conversations, all having as their focus the realities and challenges of the urban reality, and in particular the City of Tshwane ${ }^{1}$, and to different degrees, the vulnerable city, or the city of particular vulnerabilities (cf. Section 2). These conversations are the Capital Cities Research Project of the University of Pretoria (Faculty of Humanities, University of Pretoria 2013), feast@ UP (De Beer 2014:138-139; Feast of the Clowns 2014), the Biennial Consultation on Urban Ministry (Un-shack-led 2014), the Meal of Peace Project (Methula 2014:107), and the Homeless Summit (Faculty of Theology, University of Pretoria 2015).

In this article I explore the metaphor of the clown to consider the relationship between the university and the city. More specifically, I consider the clown as metaphor for the activist scholar or liberation theologian working at the public university. Stumbling into urban spaces, the clown embodies frailty and feebleness, yet provides unnerving and honest critique, telling the emperor he or she is naked, without fear or favour, and potentially unshackling shackling liaisons that might deal death. Occasionally, when the clown is not regarded as official jester, or busy bringing laughter into a sad world, or mourning that which makes the world sad, the clown also becomes the cross-bearer, the crucified, in deep solidarity with the crucified wretched of the earth.

Although informed by local and trans-disciplinary engagement, this is a theological essay, seeking to reflect on the possible relationship between the university and the capital city from a theological and faith perspective. It gives specific consideration to what it could mean to be a contextual urban theologian, or liberation theologian, or activist scholar working at a public university, with a deep desire to engage faithfully with both local urban contexts of struggle and vulnerability, as well as with the public university in whose employment one is. It considers solidarity, mutuality and prophecy as clown-like postures with the ability to deconstruct, liberate and transform urban people, places and institutions alike, if only there is a deep willingness to embrace such unnerving postures, recognising our own deep frailty and limitations of knowing.

This article should be read against the backdrop of the broader series of articles under the rubric '(un)shackled', as well as the series of conversations that helped frame the content of this article.

1.Pretoria is (still) the official name of the administrative capital city of South Africa. The City of Tshwane is the name of the larger metropolitan municipality to which Pretoria belongs. For some years now the possibility of changing the name of Pretoria to Tshwane has been on the cards. 
'(Un)shackled' was chosen as the topic of a number of these conversations in 2014, considering it was the year of celebrating freedom and democracy in South Africa, 20 years after apartheid. It was an attempt to celebrate multiple new freedoms whilst discerning and naming persistent and new shackles that still oppressed people and communities 20 years later.

\section{Five conversations on the university, the city and urban vulnerability: '(Un)shackling liaisons'}

Five independent yet often (not in every instance) interrelated conversations informed this series of articles, but also this specific article. All of them consider the relationship between the university, the city and urban vulnerability, in some form or another.

Firstly, the Capital Cities Institutional Research Theme (Faculty of Humanities, University of Pretoria 2013) was conceptualised and launched at the University of Pretoria in 2012. Its aim is to consider capital cities, particularly in the global south, and how they mediate space, justice and belonging. In this project there is a natural focus on the City of Tshwane, South Africa's capital city, although not exclusively. The project draws diverse researchers from different disciplines, representing different research interests, epistemologies, and theoretical points of departure. What is held in common is an interest to produce knowledge in the context of capital cities; however, there is probably a lack of coherence in the current approach due to the diversity of interests and approaches, as well as a lack of clarity as to how the university understands its relationship to the city, and in particular its relationship to political power on the one hand, and urban vulnerabilities on the other. There are different and sometimes contesting voices in this regard, but mostly this seems to be left unarticulated in terms of the overall project which is probably to the detriment of what this project's potential liberating or transformative contribution could be.

The sub-theme of this project - space, justice, belonging - is particularly interesting in the context of capital cities, but also needs to be clarified: Which and whose spaces? What are the indicators for measuring degrees of justice? How is belonging, as well as the quality thereof, assessed? Just in terms of the project title itself, much more should probably still be done to gain greater depth and to open up new and liberating conversations.

Acknowledging the possible tensions that exist in terms of how the relationship between the university, the city, power and powerlessness is understood, or needs to be framed and processed, a colloquium was devoted to this topic in August of 2015 as part of a second but related conversation. It was especially interested in the ways in which the university relates to the city in terms of urban vulnerability and furthering urban expressions of justice.

The second conversation is a creative collaboration that was launched in 2012, called feast@UP (De Beer 2014:138-139; Feast of the Clowns 2014). Feast@UP was initiated and is coordinated by the Centre for Contextual Ministry in the Faculty of Theology at the University of Pretoria. It is a small collaborative project with the Feast of the Clowns, an annual inner-community festival hosted by the Tshwane Leadership Foundation, a faithbased community organisation committed to the socio-spiritual transformation of the city. The purpose of feast@UP is to foster citizenship for social justice amongst academics and students at the University of Pretoria. Being aligned to the Capital Cities Project, it could be argued that feast@UP's contribution to the Capital Cities Project, in a very small way, is to theoretically consider, and practically foster urban citizenship for social justice in the context of the capital city.

This needs to be read in the context of what Giroux (2013) asserts to be the 'increasingly irrelevant' questions to be asked at neoliberal universities:

How education might enable students to develop a keen sense of prophetic justice, utilize critical analytical skills and cultivate an ethical sensibility through which they learn to respect the rights of others.

In 2014, the theme of the Feast of the Clowns, and correspondingly of feast@UP, was (un)shackled. It sought to create space for celebrating new freedoms since 1994, but also for naming old and new shackles still oppressing people and communities and preventing them from enjoying fullness of life. To tie in with this theme, the colloquium hosted in 2014 was entitled '(un)shackling liaisons: the university, the city and the clown'. The metaphor of the clown was explored to consider the relationship between the university and the city. Presentations dealt with the etymology of the clown, the academy as a game, the frailty of the city, and a shackled liberation.

Thirdly, the Biennial Consultation on Urban Ministry (Un-shack-led 2014) is hosted by the Institute for Urban Ministry in collaboration with the Centre for Contextual Ministry at the University of Pretoria and a number of other faith-based organisations. Being part of the same movement of faith-based community organisations that initiated the Feast of the Clowns, the same theme of '(Un)shackled' was adopted for the 2014 Consultation, but with a sub-theme - 'Faith and the city 20 years later' - positioning this conversation differently, focusing on discerning the role of faith, spirituality and the church in post-apartheid South Africa and in the context of ongoing shackles of oppression and exclusion. This project also forms part of the individual research of different practising theologians, as well as the Centre's own 'Faith in the city' research project, and it brings together 250-300 urban ministry practitioners, urban theologians and leaders from social movements from across South Africa and beyond.

Fourthly, the Meal of Peace Project is hosted in the Discipline of Christian Spirituality, Church History and Missiology at the University of South Africa (cf. Methula 2014:107). Researching homelessness through contextual Bible studies between researchers and people who are homeless themselves, this project is surfacing innovative readings of 
the biblical text through encounters with the streets, but also documenting narratives of homeless and former homeless people in ways that describe street homelessness and its changing face in the City of Tshwane. The different contextual readings raise important questions for theological reflection and are potential tools for unsettling or unshackling historical academic and ecclesial engagements and commitments.

The fifth conversation, in which many of the abovementioned conversations overlap, is the Homeless Summit (Faculty of Theology, University of Pretoria 2015), a collaborative research project between the University of Pretoria, University of South Africa, City of Tshwane and Tshwane Homelessness Forum, to discern pathways out of homelessness and to inform the city's policy and strategy to engage and address street homelessness. Preceded by an intensive research project, the actual Homeless Summit took place on 25-26 May 2015, gathering more than 400 people, including more than 200 homeless people, academics, city officials, politicians, NGO and church leaders and representatives from business and the police, to reflect on possible pathways out of homelessness.

What do all these ongoing conversations have in common?

- All five conversations, from different angles, consider the relationship between the university and the city, and in particular the relationship between university and city with reference to urban vulnerability, urban spacemaking, access to justice and the notion of belonging.

- All five conversations, even if not always consciously so, raise questions as to the role of the activist scholar or liberation theologian, both in naming shackles and in mediating alternative imaginations.

- From my own perspective as a participant in these conversations, theological and faith perspectives are explored in all five conversations: questions of human dignity and Christian solidarity; the household (oikos) of God and mutuality; life-giving cities and neighbourhoods and God's shalom; homelessness and home-coming; and urban injustices and Christian prophecy are all theological themes appropriate to all five conversations.

\section{(Un)shackling the city of capital}

The capital city is not a narrow description of only those cities serving as political seats of power; it also refers to provincial capitals, financial capitals and other cities having particular prominence due to their functional importance in a country or region. When I consider the capital city in the context of this article, I locate my reflections mainly in the City of Tshwane, considering its function as capital of South Africa's political administration, but also the way in which capital, and Tshwane's embeddedness in the political economy of the Gauteng City-Region, shape the city in terms of space, justice and belonging. In a real sense the question is whether Tshwane is firstly the capital city in a political sense, or firstly a city of capital, in which economic forces dictate political agendas and outcomes and the realities of vulnerability, inclusion and exclusion.
Giroux (2013) speaks of 'the mantras of neoliberalism' as government being a problem, society mere fiction, sovereignty being market-driven, commodification a vehicle for increasing freedom, and higher education a servant of corporate interests instead of serving the public good. Both city and university could therefore be interrogated in terms of in how far they dictate their own terms, or whether their terms are dictated for them by the forces of capital and the market.

It could be argued that the capital city, even though framed politically by the ruling part (in the context of the City of Tshwane) as participating in the national economic revolution, is essentially a pawn and instrument of capital in its crudest sense. Soja discussed David Harvey's insights into urban capitalist processes as follows:

[T] he 'normal workings' of the urban system, the day-today practices and particularities of urbanism as a way of life, tend all on their own to produce and reproduces a regressive redistribution of real income that persistently benefits he rich at the expense of the poor. Harvey described the capitalist city as an inequalities generating machine by its very nature, thereby creating in the context of urban geographies and the counter reactions of social processes and spatial form a fertile terrain for the accumulative aggravation of injustices. (Soja 2000:107)

Urban inequalities result from the ways in which the market economy determines property values, choosing where to invest and where not, and colluding in the exclusion of those who are poor from benefiting and participating on equal terms. This is further exasperated by the ways in which urban planning professionals and public sector officials make decisions that are, due to their lack of control over market forces, simply co-opted by capitalist forces to further contribute to inequalities (cf. Soja 2000:107). Soja, Harvey and others like them would probably assert then that the real forces shaping the city have little to do with political power, but more with the ways in which political power has been absorbed into capitalist market economies.

The sale of public land to the highest bidder, at the expense of mediating the much lamented lack of spatial transformation and spatial justice, and the different ways in which the monumental outweighs the ordinary in capital projects undertaken by the city, are stark reminders of the ways in which the City of Tshwane, for example, participates in a neoliberal capitalist economic system, probably to the detriment of the majority of its inhabitants living on the urban margins.

\section{David Harvey (1978) describes how}

capital represents itself in the form of a physical landscape created in its own image, created as use value to enhance the progressive accumulation of capital ... Under capitalism, there is a perpetual struggle in which capital builds a physical landscape appropriate to its own condition at a particular moment in time, only to have to destroy it, usually in the course of crises, at a subsequent in time. This temporal and geographical ebb and flow of investment in the built environment can be understood only in terms of such a process. (p. 124) 
Urban spaces in the capital city are never neutral, but are manipulated by capital, in conjunction with political power (cf. Terreblanche 2014). That is why the inner city of Tshwane could experience the ebbs and flows that Harvey describes, at one point a desired destination by capital and political power (pre-1994), then redlined by banks and discarded by commercial and political interests (1994-2004), then again selectively embraced on terms not determined by those living in these communities, but mostly by external interests (2004-today).

In response to such manipulations of political and economic power, what is today often known as the dual processes of urban flight and the corresponding processes of urban gentrification - first abandoning the poor by disinvesting, and then displacing the poor by investing - Lefebvre (1996) introduced what has become a crucial school of thought, considering who has a 'right to the city'. He reflected on social struggles over 'the production of space' - how urban spaces are made, by whom and for whom - and suggested the need for an 'urban revolution' (cf. Soja 2000:101) expressed in the participation of inhabitants of the city who will participate in the production of urban space, contrasting the largescale socio-spatial exclusion with which Lefebvre became concerned.

When the university then engages in an institutional research theme entitled 'capital cities', considering the ways in which urban spaces are not neutrally shaped, and political power as subservient to the power of capitalist forces, it is critical to consider the nature of the university's engagement with the city in terms of its research, teaching curriculum and community engagement programme: Is it an engagement of critical solidarity with economic and political power, or an engagement of prophetic solidarity with the urban poor and excluded? Can it be both at the same time? Is it a deconstructive or reconstructive engagement; a sanctioning or dismantling of death-dealing forces; an exploitative, selfserving and death-dealing engagement or empowering, generous, and life-giving?

The role and function of the activist scholar and liberation theologian in this regard is crucial. They have to ask these critical questions of the city, and of the university in relation to the city; they are the ones to name the shackles and manipulations of power, but also to accompany processes dedicated to finding radically inclusive alternatives. But finally, they are also the ones who have to start embodying the viable responses to their own questions.

\section{(Un)shackling the neoliberal university}

The problem is the university's own increasing complicity in and subservience to neoliberal economic forces, disabling it from speaking critically into the reality of an exclusivist urban political economy. Today's university has been largely absorbed into the template of neo-liberalism, whether in Asia, North America, Europe or Africa, and should a university desire to participate as a competitor in the global game of world rankings and profitable academic enterprise, the same neoliberal processes and priorities apply.

The characteristics of the neoliberal university, which is probably the twin of the neoliberal city of capital, are the same everywhere:

- Firstly, the neoliberal university is an important participant in producing 'neo-liberal globalization', which includes the 'reproduction of capitalism and class society', sustaining 'corporate power', the 'militarization of society' (and of university campuses) and contributing significantly to 'local gentrification' (cf. Chatterton, Hodkinson \& Pickerill 2010:262, 263).

- As an agent of neoliberal capitalist reproduction, the 'market' then becomes the basis for organising the university and its relationships with the outside world (Ball 2012:17; Shamir 2008:3).

- When the market becomes the basis for organising the university and its relationships, it obviously means, and requires, the commodification of knowledge production (and of the neoliberal university as a whole) (Chatterton et al. 2010:261): research and teaching are now increasingly and intentionally having to be 'designed to serve corporate interests as well as increasingly commercialised in order to attract more income and investment' (Chatterton et al. 2010:261). In the process of such 'academic capitalism', as Slaughter and Rhoades (2000:73) call it, 'which speaks to the move toward the marketplace', critical thinkers are reduced to academic bureaucrats or cogs in a machine.

- In such a scenario, performativity and productivity become more important than experience and wisdom (cf. Ball 2012:19). As Ball (2012:17) says: 'to make myself calculable rather than memorable', and 'reporting on what we do rather than doing it' (Ball 2012:19). The academics are required to be enterprising 'specialists without spirit' (Ball 2012:18), and their marketability becomes a central drive. Ball (2012:19) suggests that ' $[t]$ here are new sets of skills to be acquired here - skills of presentation and of inflation, making the most of ourselves, making a spectacle of ourselves' (Ball 2012:19).

- Once the shift took place to a neoliberal agenda, even if not articulated as such by university management, there is increased differentiation between university management and academic staff (Giroux 2013), labour becomes increasingly alienated, exploitative and hierarchical, and hierarchies use surveillance to keep subjects in check (cf. Chatterton et al. 2010:262). Slowly academic staff are remade into 'managed professionals which has to do with the pattern of increased managerial control of faculty' (Slaughter \& Rhoades 2000:73).

In how far is the university losing her soul in the process? What are the shackles that come with the university's participation in the neoliberal agenda? Even though compromised, can the activist scholar or liberation theologian, as participants and employees of the university, simultaneously resist forces that threaten the vocation of the university? 
Of course it depends on what is regarded to be the main vocation or function of the university. The departure point of this paper would be to align itself to Giroux (2013), suggesting that

$[u]$ niversities should be subversive in a healthy society, they should push against the grain and give voice to the voiceless, the unmentionable and the whispers of truth that haunt the apostles of unchecked power and wealth.

Many activist scholars could fall into the trap of engaging and supporting 'the struggles of "others"', as Chatterton et al. (2010:250) indicate it, but'usually making no connection with how "we" uncritically support the university, and are small but significant actors in creating that injustice' of exclusivist production of knowledge, alienation of labour and corporate power.

\section{The public university's clown: The function of activist scholar or liberation theologian}

Chatterton et al. (2010:247), in reflecting on 'scholar activists' challenge what they call 'a false dichotomy between academia and wider society in terms of sites for social struggle and knowledge production'. They take to task those so-called scholar activists or activist scholars, as I suggest they should be called, who reserve their activist work for evenings or weekends, thereby reinforcing the idea of separate worlds without integrating their activism into their academic reflection. Or, worse even, they speak of academics reflecting on the struggle of others but in ways that only 'build their careers on the backs of researching the oppressed' without really joining their struggle (Chatterton et al. 2010:247). In this scenario, knowledge production often remains the monopoly of the university, and engagement almost 'professional charity' by academics, instead of participating citizens engaging issues of mutual interest in solidarity with many others (cf. Chatterton et al. 2010:247).

Inherent to the notion of activist scholar is a praxis-approach seeking to integrate action and reflection into an ongoing cycle of engagement. Often though, engaged action and secluded reflection are posed as opposites seemingly not belonging together. The liberation theologian, as activist scholar or reflective practitioner, seeks to intentionally live the paradox of being with one foot in the realities of the poor and vulnerable city, participants and agents of struggle, yet with another foot in the academy, where similarly they are participants and agents of similar but different and often interrelated struggles.

However, it is not that simple. In their self-critical reflection on activist scholarship, Chatterton and his colleagues (2010:251) speak of the sobering experience they had when civil society organisations assessed their engagement as 'exploitative, unaccountable, managerialist, and compromised by our academic status'. Those assessing them basically suggested that their scholarship and their activism were mutually exclusive, and it is this difficult paradox that the activist scholar, or liberation theologian, seeks to integrate into themselves.

Messer (1989:116-134) speaks of paradoxical images of Christian ministry, and a number of these images are helpful to unpack this dual function of the activist scholar or liberation theologian. Messer (1989:116-134) speaks of the practising theologian and the political mystic. The practising theologian is one who seeks to bridge action and reflection, or practise and the reflection on practice. The political mystic is rooted with one foot in the messiness of the polis, but with the other foot in a spirituality that seeks to make sense of the polis whilst perhaps creating meaning in the midst of its messiness.

It is precisely this paradoxical tension that is expressed in a praxis-approach, continuously engaging in an action-reflection cycle being informed by these different modes of engagement. Soja (2000:74) defines praxis as 'a Greek word referring to the transformation of knowledge into presumably beneficial, progressive socio-spatial action'. In the context of this article, activist scholars at public universities are recognised as people following a praxis-approach which allows for knowledge to be transformed by different engagements with different publics, and particularly 'from below', in order to mediate socio-spatial action that will have liberating and transformative results. It refers to academics who seek 'to place their teaching and research at the service of radical social change' (Chatterton et al. 2010:246)

Boff and Boff (1986:27)² suggests that the liberation theologian is not a classroom or study intellectual, but an 'organic intellectual', a struggle theologian ('een strijdbare theoloog'), with one foot in the centre of reflection and the other foot in the life of the community. The Boffs say one will find the liberation theologian deeply engaged in the midst of and with a concrete community, embodied, located, with body and soul ('met lijf en ziel').

In reflecting on the life and work of African-American philosopher and ethicist Cornel West, George Yancy (2001:7) speaks of him as one who enacts the vocation of an organic intellectual, 'one who is an activist and engaged, not hermetically detached', suggesting West as 'a powerful example of how the intellectual life of the mind can be deeply ensconced in the realities of political everydayness ... [b]lending critical reflection and political praxis'. Yancy's reflection seems to suggest that West is able to integrate these seemingly paradoxical moments of reflection and action into a coherently lived praxis.

Although teaching at the prestigious institutions of Harvard, Princeton and Yale, Cornel West does not seem intent on

2.Since the writing of this book the two Boff brothers parted ways theologically Leonardo remained faithful to the tenets of liberation theology. In 1985 he was silenced for a year by the Congregation for the Doctrine of the Faith then under silenced for a year by the Congregation for the Doctrine of the Faith, then under the leadership of Cardinal Joseph Ratzinger, who later became Pope Benedict XVI. When the church tried to silence him again in 1992 he left the Franciscan religious order and the priesthood (Cox 1988:178-188). Clodovis however distanced himself from some of his earliest liberation theological perspectives and also of his brother's strong critique of ecclesiastical traditions. In the 80 s he lost his professorial position as a result of his teaching, but is currently teaching again at the Pontifical Catholic University of Paraná. 
being shaped in their image, but rather desires, in his own words, 'the courage to love enacted by a Palestinian Jew named Jesus, who was crucified by the powers that be, betrayed by cowardly comrades and misconstrued by corrupt churches' (West 1999:xvii; cf. Yancy 2001:9). In writing about West, James Cone says, 'West perceives himself to be an intellectual freedom fighter who happens to be a university professor'. His pursuit for freedom and justice is central in his activist scholarship, with clarity of purpose which West himself describes as such: 'the condition of truth is to allow suffering to speak' (West 2014).

It is the condition of suffering that probably shapes the agenda of the activist scholar to a large extent. Giroux (2013), for example, advocates for a 'pedagogy of wakefulness' as an ethical and political practice, single-mindedly devoted to alleviating human suffering. He speaks of a

pedagogy that demands a critical and engaged interaction with the world we live in mediated by a responsibility for challenging structures of domination and for alleviating human suffering ... As an ethical and political practice, a public pedagogy of wakefulness rejects modes of education removed from political or social concerns, divorced from history and layers of injury and injustice.

Messer (1989:116-134) uses another paradoxical image, that of the enslaved liberator, which I find particularly helpful in unpacking the function of the activist scholar or liberation theologian at the public university. Being an integral part of the culture of the institution and the city, and yet, seeking to identify, name, resist and overcome the trappings or oppressions of the institution and the city, are the tensions within which the activist scholar seeks to do scholarship or, in the case of the liberation theologian, theological scholarship. In Messer's language this means someone who is at once enslaved and therefore compromised, yet, seeking passionately to facilitate multiple freedoms from that which enslaves. Stephen Ball (2012) describes this ambiguous captivity between worlds, saying:

... even as I write I am aware, in the neoliberal bits of my soul, of the impossibility of what I seek to defend - that which the University 'can alone do and do bes' (Kumar 1997:29), to enable people to think. (p. 19)

The metaphor that I propose in this article, and for further reflection, is the metaphor of the clown. I suggest that this metaphor could assist a reflection on the nature and function of activist scholarship at the public university. On the one hand the clown is all of us, in our frailty and miserable inability to outwit the workings of the market and the empire (enslaved). And yet, the clown, in offering an honest mirror, at the same time is offering a profound critique (liberator). Surrounded by the shackles of human existence, immersed in human suffering himself or herself, it is the shackled clown, not free from human frailty, that also offers small glimpses of possibility out of the shackles' binding hold.

The clown as jester is almost a requirement for both university and city, if these publics are to remain truthful to their own vocations and truthful to those dependent on them for education, habitation and/or sustenance. The clown as jester is the one authorised to speak truth to power and to tell the emperor when or if he or she is naked. Without the presence of this particular clown, the empire of the emperor might continue to turn inhabitants into victims, participants into cogs of a neoliberal machine, and subjects of liberation into objects of manipulative markets. It is the clown as jester that the activist scholar is invited to be.

Lewin (1987:236) quotes the South Korean theologian and peace activist, Jae Shik Oh, who very powerfully likens Jesus to the clown, in reference to Philippians 2:5-8. In this text, Christ Jesus is depicted as one who was equal to God, yet instead of grasping equality he humbled and emptied himself, making himself in the likeness of servants, slaves and humanity, unto death on a cross. It speaks deeply of solidarity and mutuality, and in his voluntarily surrender of power also becomes a powerful prophecy against the manipulative powers of empire and capital. In reference to this text, Oh then said:

This is the role of the clown. Jesus was made into a clown. The organizer is a clown. You make yourself nobody, empty yourself, to be filled by the people's agenda. If we learn this lesson carefully, then we become very sure and are competent to go on organizing. The organizer shouldn't be seen on the surface. The organizer must be prepared to give up his or her own life. The organizer should not claim the process. (Lewin 1987:236)

Oh referred to the role of community organisers working with poor communities. But similarly the role of the activist scholar, liberation theologian, or organic intellectual, could be seen as that of the clown, allowing the questions and agenda of the people to become one's primary research questions and agenda. The clown mirrors the struggles of people and communities, and the activist scholar as clown would therefore allow the struggles of people and communities to question, subvert, inform and liberate the questions, agendas, curricula and outcomes of the university.

In relation to the specific function of the liberation theologian, although the same would apply to the activist scholar in general, Boff and Boff (1986:28) speak of the diverse challenges and requirements facing them. The liberation theologian has to be engaged concretely-politically in communities, pastorally in faith communities, and theologically in the academy. This almost always means that the liberation theologian is tired and challenged beyond what they are able to do alone. Therefore, the Boffs hold, the task of such theology is always to be done collectively, in organic relationship with the church in all her different expressions. Similarly, activist scholars working in individual isolation would soon find the requirements of their work overbearing, and therefore they too need communities in which collective commitments and reflections could be undertaken to help sustain the rigour of a praxis-approach.

Apart from the necessity of collective action to sustain movements for change, it is also about a more strategic approach to activist scholarship, not informed merely by individual 
agendas, but by collective discernment of research priorities, and even more, by research questions and needs arising from within and articulated by communities (cf. Chatterton et al. 2010:250).

Boff and Boff (1986:32-52) in this regard speak of three mediations facilitated by liberation theology, or by communities engaged in action-reflection cycles: firstly, a socioanalytical-political mediation (immersed in solidarity with the world of the poor, articulating concerns from this world); secondly a theological-hermeneutical mediation (immersed in a relationship of mutuality with both faith community and the community of the poor, which sometimes overlap, discerning and articulating the vision of God); and thirdly, a practicalpastoral mediation (embodying a prophetic alternative).

The rest of this article suggests the three postures of solidarity, mutuality and prophecy, almost the clown-like postures of the Boff's three mediations, to resist the shackles of culture (culture in the broadest sense of the word) and to imagine and embody daring alternatives.

\section{Solidarity: A theology of presence}

Solidarity in a theological sense is about creating and maintaining an incarnational presence with and alongside particular people and places, standing, struggling and celebrating together. As a clown-like posture this is not a perfect orderly presence but most often a 'not-knowing', stumbling presence, standing and struggling without necessarily being able to anticipate clear outcomes.

For the activist scholar or liberation theology it will probably include solidarity with the local, solidarity with the poor and solidarity with emerging and existing movements working for social justice.

\section{Graham and Lowe (2009) stress}

the importance of the local, as the context in which 'God takes place' ... but a local increasingly characterised by global currents: economic change, recession, cultural pluralism, mobility and migration. (p. 158)

The five conversations referred to earlier are all considering the local, but clearly within the context of various global forces at work. The task of the activist scholar would be local solidarity mediating socio-analytical understanding and articulating local concerns and hopes in the light of such mediation.

However, there is no 'neutral local' and therefore it also needs to be asked with whom or with which local the activist scholar chooses to be in solidarity. Is it solidarity with the aspirations of private sector or political power, or is it solidarity with those marginalised by the socio-economicpolitical exclusions of the empire?

Is the activist scholar deliberately setting himself or herself up in solidarity with the 'victims' of the empire, announcing to the emperor that he or she is naked? In their own project,
Chatterton et al. (2010:249) differed on methodological approach, with some of the project members opting for participatory action research that is not inherently progressive', whilst two of the project members advocated for a more radical approach informed by Italian and Argentinian struggles and associated research militancy, called 'solidarity action research' (SAR) (Chatterton et al. 2010:252). This approach goes beyond participation as outsiders peeping in for a moment to 'working ... in solidarity with groups in struggle, co-producing outputs relevant to that resistance movement and not to academia, funders or our careers' (Chatterton et al. 2010:252). There is no neutrality here, as the researcher is the fellow struggler, the companion on the road of those resisting death-dealing forces, whatever they might be discerned to be.

The departure point of this article is a clear position of solidarity with the poor, expressed in a preferential option for the poor (cf. Boff \& Boff 1986:53). The first priority for Cornel West is '[a]ctive solidarity with the poor - physically, spiritually and psychologically' (Cone 2001:109). Similarly, Gustavo Gutierrez did not only write eloquently about an option for the poor, but embodied it living most of his own life, whilst being a university professor, in the slums of Lima, Peru.

In arguing a preferential option for the poor, Gutierrez (1988:xxv, xxvi) holds that this is not an exclusive option against others, but a preference given to those excluded, oppressed or marginalised, as our first solidarity, precisely because they are outside. Theologically, this commitment or preference is not to be found firstly in our social analysis, or human compassion, or our own experience of poverty even, but in Christ's own close identification with 'the other', being the stranger, the hungry and the prisoner (Mt 25). It is, says Gutierrez (1988:xxvii), 'a theocentric, prophetic option that has its roots in the unmerited love of God and is demanded by this love'.

A clown-like posture of solidarity will not only show itself in solidarity with specific local struggles, or in practising an option for the poor or vulnerable, but will also be expressed, consistent to the previous two solidarities, in its solidarity with existing initiatives or movements working for justice. It is clown-like in its exposure of the spectacle of power, showing it up for what it is, through its simple solidarity with powerful people and place. The nature of solidarity is in contrast to approaches doing things or thinking for people, but is standing and struggling with people. Again, the clown comes as the archetype of human silliness to be with the people, showing them themselves in the clown as mirror. Activist scholars and liberation theologians are therefore not deciding the agenda of their research or engagement always, but, in journeying with and alongside existing movements working for social justice, research questions and agendas for engagement that are often articulated together or emerging from deep engagement with the poor and/or practitioners engaged at local level.

Boff and Boff (1986:12) speak of the ways in which the poor overcome their struggles through designing potent strategies 
to transform their social relationships. This occurs through recognising the causes of their oppression, conscientisation, organising their own movements, and developing and implementing strategic plans of action. This, they say, is the first step of liberation (theology): where the poor act collectively and consciously for their own liberationtransformation (Boff \& Boff 1986:10-13). The second step is faith(ful) reflection on acts of liberation. The function of theology in such relationships with the poor or with grassroot organisations, is to ask how faith communities, or the university, could and should contribute to actions and practices initiated by the oppressed for their own liberation (Boff \& Boff 1986:13)

The task of liberation theology becomes one of discerning and exploring ways in which faith communities could act in solidarity with the poor (in the broadest sense of the word), and with those of good faith and good will who are already standing in solidarity with the poor. A theology of liberation, for Boff and Boff (1986:15), is reflection on practices for liberation, with those who are poor and oppressed, inspired by our faith and the gospel, and in the interest of the integral liberation of the whole of humanity, the whole person, and every person.

Before stumbling from this posture to an embrace of mutuality, the problem of critical solidarity as a proposed way for engaging those in power needs to be mentioned. In the 1980s and early 1990s Afrikaans theologian Johan Heyns propagated critical solidarity or critical identification with the government of the day (Landman 1996:356). Critics of his held that there was a greater focus on identification than critique. Post-apartheid theologies of reconstruction similarly proposed critical solidarity with the new democratically elected government, challenged by someone like Vellem (2013). In the context of this paper, critical solidarity could also refer to a possible relationship with the university or with the city in which one engages. The problem with a proposal for critical solidarity, however, is its almost inevitable complicity with power and the way in which such solidarity will always taint its possible prophetic witness.

Theologically the solidarity of Jesus was never with the empire or the religious establishment: what Jesus came to establish was a counter-movement at odds with empire and religious establishment; an upside-down community that expressed itself firstly with 'the other': the excluded women, the blind and the lepers, the Samaritans and the outcasts. Jesus was in solidarity with all of broken humanity, but in particular with those who are victims of state and religion (cf. Kairos Southern Africa 2011; Vellem 2013). The engagement of at least the liberation theologian with the city, university and empire at large, even though at times deeply constructive, would therefore also be from a place of primary solidarity with Jesus in the poor. Jesus entered as clown on the back of a donkey, in solidarity with the outsider, in exposure of the ways of the empire. The liberation theologian remains engaged in the tradition of the clown-like Jesus.

\section{Mutuality: A theology of community}

Mutuality is about acknowledging our deep interdependence and the necessity to foster new kinds of collaborations and communities that can overcome our multiple fragmentations. In solidarity, new kinds of mutuality are fostered, expressed in innovative and liberating collaborations, and the sharing of different and complementary knowledges, taking local contexts, people and their unique wisdoms seriously. Activist scholars, community practitioners, homeless communities and city officials might now actually find common tables to sit at, for the negotiation and imagination of radical new urban engagements.

Elaine Graham and Stephen Lowe (2009:37) speak of the response to 'modernist urban planning in favour of a bottom-up, grassroots approach, in which participatory models of urban design and community development are preferred to the centralized, technocratic planning of an earlier generation'. The clown makes fun of the technocrats, being playful, and makes a mockery of their protocols which bring division. At the opening of the Tshwane Homeless Summit on 25 May, after politicians and officials observed many protocols in respect of each other, almost forgetting the actual reason of the event which was the centrality of people in their midst who were homeless, anthropologist Rehana Vally (2015) stood up and lamented the state of affairs. Through her words she subverted protocol, pushing those on pedestals to their chairs, and inviting those from the streets to theirs, so that everybody could be seated as equals around equal tables.

Mutuality is about new playing grounds where the tables are equal and hierarchical relationships and understandings of knowledge subverted and replaced by relationships of shared mutuality. Suddenly knowledge is not the sole domain of the academic, activism is not the exclusive right of the practitioner, and the technocrat is invited to participate in playful (re)imaginations of serious death-dealing situations.

Andrew Davey (2008:43) compares emerging urban churches and new social movements scattered all over the urban landscape. He identifies parallels between what he calls the 'performative theology' of urban churches and 'performative urbanisms' of the new social movements. Both urban churches and new social movements, committed to more radical urban change, share certain similar characteristics: embodiment, imagination, the importance of the local, and networks of mutuality. Broadbased movements emerge that combine embodied and immersed solidarity and action, informed and sustained by bold imagination and partnerships of deep mutuality and mutual accountability. But there is also a performativity to them that is directly countering the performativity that Ball speaks of when describing the neoliberal university (cf. point 4 here above). The content of performativity in this case is clown-like, at once resisting, celebrating and imagining, and 
permanently finding creative and subversive ways to create new and circular tables of shared mutuality, contrasting the performativity that alienates a worker from his or her labour and the academic from the neoliberal managerialist institution.

The kind of mutuality I suggest in the context of the city, the university and the activist scholar or liberation theologian, should be expressed in different spaces.

- It will include ways in which theology engages different disciplines, not in an artificial attempt at inter-disciplinary work, but in ways that truly affirm the interdependence of knowledge and enquiry, and the necessity of new kinds of communities that deliberately resist isolation and transcend unacceptable and often illogical disciplinary boundaries.

- It would include the ways in which different knowledges are recognised and invited in a deliberate subversion of hierarchies of rationality. It would create collaboration between the university, the city's officials and politicians, and local urban neighbourhoods and community leaders, allowing different and even contesting voices to listen carefully, respectfully and honestly to each other.

- It will create spaces in which vulnerable populations, researchers, activists and bureaucrats can articulate themselves in the presence of one another, in ways that build new bonds of trust and create better and mutual understanding.

- It will mediate spaces in which city, university, civil society and church can discern together what a good city might look like, and how different partners should contribute to ensure a city that is good, humane, hospitable and just.

- It will facilitate spaces that deliberately subvert hierarchical presumption and allow for equal engagement that liberates all participants at the table.

For such mutuality to be fostered, for such new and disarmingly different tables to be created, the clown probably needs to be present: to remind us of our collective and mutual frailty, to help us imagine new ways of being human, and to show up our false certainties the moment it starts to surface.

If liberation theology is historically seen as rivalistic in its critical, resistant and deconstructive manner, this is not to be tempered, but to be complemented with an imagination of alternative possibilities, and with developing, proposing and embodying such possibilities in concrete ways and places. The liberation theologian will sit at tables of mutuality, always having the poor at heart, ensuring that the poor themselves are also at the table, and assessing the quality of the table in terms of the ways in which it mediates liberation and empowerment from vulnerability, and increased access to different forms of justice. It therefore is not a neutralizing mutuality, but a discomforting mutuality, because it continues 'to allow suffering to speak' (cf. West 2014).

\section{Prophecy: A theology of resistance and imagination}

Muers (2011:40) echoes Graham and Lowe's emphasis on the local, suggesting that the 'truly prophetic response in the contemporary situation ... is always local, "rooted", materially constituted by the particular context in which it emerges'. That is why rootedness in a local context is important for the activist scholar or liberation theologian who wants to remain true to their roots and vocation: this is where prophecy is birthed and nurtured.

Solidarity with vulnerable people and places, if honestly and authentically practiced, will almost always give rise to prophecy: a clear and unequivocal commitment to an imaginative alternative to the status quo, and a fierce and articulate resistance of that which sustains a status quo that violates and excludes. The activist scholar or liberation theologian will practice such a twofold function of resistance (unsettling, discomforting and unshackling) and imagination (fantasizing about and celebrating possible alternatives). It is not necessarily prophecy uttered or enacted by radically free people, but often by the enslaved liberator, or the slave himself or herself, seeking to resist and overcome that which enslaves, whilst imagining the radically different. In the context of 'authoritarian forces circling the university', Giroux suggests that ' $r r$ esistance is no longer an option; it is a necessity' (Giroux 2013). If the activist scholar cannot cut their teeth into prophetic resistance within the university, there is little integrity in the struggles they seek to align themselves with in the urban public.

However, the activist scholar would probably always remain as rare a breed as the clown. Cornel West (2014) cautions against the idea that it would be the masses ushering in change, referring to every significant transformation or revolution the world has ever seen. He says it in his own poetic way: 'It's never the vast minority; it's a highly qualitative slice of a minority who are on fire that begin to call into question the luke-warmness of the mainstream and the mainstream begins to tilt in a opposite direction'. It is the prophetic resistance and imagination of a remnant of prophetic voices that has the potential to tilt the mainstream into an opposite direction. Initially such voices would be laughed off as mere clowns, not to be taken seriously - until the truth could be discerned for what it is and change might happen.

And yet, such prophecy is not just resistance in the sense of cynical opposition or imagination in the sense of utopian fantasy either; it is rooted locally, as Graham says, and requires a combination of resistance, imagination and imaginative, bold and pragmatic action. Perhaps the life of Patch Adams (Adams \& Mylander 1998), the clown and medical doctor after which the movie was made, is telling. Patch resisted a dehumanised and dehumanising health care system, he boldly imagined a more human, humorous, loving, and liberating alternative, which he then creatively set out to embody that in concrete projects in local realities. 
Patch, the clown, was not just fooling around, because the seriousness of his passion required concrete actions that could usher in a different world.

Emanating from a love ethic seeking to resist evil and injustice, West has embraced what he himself calls a prophetic pragmatism (cf. Yancy 2001:9). He describes prophetic pragmatism as the 'leaps of faith in the capacity of human beings to transform their circumstances, engage in relentless criticism and self-criticism, and project visions, analyses, and processes of social freedom' (West 1988:38). These are, therefore, in his mind, not merely philosophical abstractions, but they also find expression in the articulation of concrete visions and processes that have the potential to mediate imaginative alternatives, social freedoms, and sustainable change.

In nurturing a prophetic consciousness and pragmatic prophetic practices the five modes of prophetic speaking of Koopman (2015:142) are helpful: criticism, envisioning, story-telling, technical analysis and policy-making. The proposal of this article is that the activist scholar or liberation theologian needs to embrace the postures of solidarity, mutuality and prophecy. And prophecy should not be reduced to critique or even viable imaginations of alternatives to that which is critiqued, without also starting to give concrete expression to what is imagined.

The first mode of prophetic speaking suggested by Koopman (2015:142) is that of criticism. Criticism entails both self-criticism and public criticism. Criticism often precedes envisioning and is the task of deconstruction and denunciation. The clown, the jester, the satirist, the activist scholar have different languages with which to critique, denounce or unmask.

Where the visionary task entails annunciation, the task of criticism entails denunciation. Where visionaries announce the liberating new, critics denounce the persistence of the oppressive old. (Koopman 2015:142)

The second mode of prophetic speaking, Koopman suggests, is that of envisioning. Envisioning is that which imagines and spells out a preferred reality, and 'a new lifestyle, new practices, and new habits and virtues' to embody such an envisioned imagination. Whereas criticism entails resistance and denunciation, envisioning entails the announcement of an alternative imagination. The clown offers a fantasy of joy and hope to children and adults alike, of a better world.

The third mode mentioned by Koopman (2015:142) is that of story-telling. Story-telling narrates and gives voice to both stories of pain and oppression, but also to possible 'hopeful and inspiring stories of victory and liberation' (Koopman 2015:142). It is a specific mode of prophecy that has the potential to invite people in, more than criticism does. The mime artist, as clown, often tells deeply moving human stories, of pain and joy that invite people in because of their close identification with the story and its characters.

The fourth and fifth modes discussed by Koopman go further than mere critique, imagination or story-telling. They are modes that in my mind seek to become rather concrete in its criticism, but also in its proposals of concrete alternatives.

Technical analysis, the fourth mode mentioned by Koopman (2015:142-143), is the process of collaborating with experts from different disciplines to do a thorough analysis of societal challenges and problems, with the view of discerning and formulating appropriate responses and solutions. It is here that the clown might want to join forces with the acrobats or set designers, to make sure that envisioned alternatives could be appropriately designed and implemented.

The fifth mode is participation in policy-making. In a sense this mode of prophecy is able to build on technical analysis, but going beyond mere analysis and even imagining of alternatives, almost culminating the work done in criticism, envisioning, story-telling and technical analysis, through the articulation of concrete policy and strategic proposals (Koopman 2015:143). There comes a time when the clown too takes off the mask. Now no longer speaking in riddles or humour, the clown makes concrete proposals for the way ahead. Right at the end of 'The great dictator' Charlie Chaplin speaks clearly and sets out what is his own agenda for a better world.

In considering the five conversations that form the background, in a certain sense, to the reflections of this article, I suggest that at least four of them have a clear alignment to the prophetic modes of speaking that Koopman proposes, in varying degrees. They probably emerged from within a similar prophetic, liberationist tradition than that of Koopman, and in at least three of the four conversations Feast@UP, Urban Consultation and Meal of Peace - the elements of criticism, envisioning and story-telling are rather central. In the Homeless Summit and the research process preceding it, all five modes were intentionally present, as this project also required a specific contribution to policy and strategy formation on street homelessness in the City of Tshwane.

Unlike these four conversations that have rather clear consensus on their respective agendas and envisaged outcomes, and often have overlaps in terms of the researchers and practitioners involved in them, the Capital Cities Research Project still raises questions with me, as you can see from the table here below. There is not a similar coherence of agenda and envisaged outcomes, which perhaps should not be expected, and the project did not emerge from within a similar tradition as that of Koopman's discourse or the other conversations mentioned here.

However, how would the activist scholar or liberation theologian engage the Capital Cities Research Project? What would their unique contribution to the process be? How would they position themselves with regard to the city, both powerful and powerless, but also with regard to the university and the Capital Cities Research Project itself? I would suggest that the five modes of prophetic speaking, as proposed by Koopman, could very well offer a suggested 
TABLE 1: Assessing five urban conversations in terms of Koopman's modes of prophetic speaking.

\begin{tabular}{lcccc}
\hline & & & Modes & \\
\cline { 2 - 5 } Process & Criticism & Envisioning & Story-telling & Technical analysis \\
\hline Feast@UP & $\mathrm{x}$ & $\mathrm{x}$ & $\mathrm{x}$ & \\
Urban consultation & $\mathrm{x}$ & $\mathrm{x}$ & $\mathrm{x}$ & \\
Meal of Peace & $\mathrm{x}$ & $\mathrm{x}$ & $\mathrm{x}$ & \\
Homeless Summit & $\mathrm{x}$ & $\mathrm{x}$ & $\mathrm{x}$ & $\mathrm{x}$ \\
Capital Cities IRT & $?$ & $?$ & $?$ & $\mathrm{x}$ \\
\hline
\end{tabular}

framework for the Capital Cities Research Project, or at least for some researchers connected to or participating in the project. If the Capital Cities Research Project does not offer prophetic resistance and an alternative imagination to current urban practices perpetuating historic and creating new sociospatial exclusions and injustices, then I would submit that it would be unfaithful to that which the university 'can alone do and do best' (Kumar 1997:29), which is 'to enable people to think' (Ball 2012:19). Of course this refers to critical reflection on practices that are death-dealing and dehumanising, in both the city and in the university.

Personally, I choose to engage the Capital Cities Research Project from within a chosen position of solidarity with particular vulnerabilities, sites of struggle and vulnerable people in the city; I seek to discern, discover and develop a research methodology that could foster mutuality in the sharing of different knowledges and experiences, subverting knowledge hierarchies and finding innovative ways of generating transforming knowledge; and, in doing so, I hope to contribute with others, and in support of existing faith communities, social movements, and community-based urban practices, to resistant and imaginative prophecy that could help embody concrete, liberating and transformative alternatives.

Table 1 attempts to indicate which modes of prophecy are practices or called forth by these different conversations.

\section{(Un)shackling liaisons? Constraints and possibilities}

The task of the activist scholar, situated with one foot in the public university, and with the other foot engaged in solidarity with particular urban vulnerabilities, is to envision the good city, in the midst of the fractured city of scars and inequalities. This series of articles, under the rubric '(un) shackled', contains (1) conceptual reflections on freedom and shackles, the relationship between the university and the city in the context of ongoing shackles and oppression, and the very nature of the university, as well as (2) particular reflections on homelessness, considered from a theological perspective, with specific reference to the City of Tshwane.

\section{Graham (2011) suggests that}

[b]uilding the good city entails thinking and acting differently against the flow of ideological versions, against the corporate vested interests, in the direction of realizing the practices of participation and re-appropriation. (p. 278)
The activist scholar or liberation theologian, clowns of city and institute, discern and name prophetically who and what the thief is who is out to kill, steal and destroy (resistance in solidarity), to evoke the language of John's Gospel in chapter 10. This prophetic clown is also consciously, and against the grain of society and the market, imagining a preferred reality of shared and life-giving abundance that is to be found, and celebrated outside of the ways of the city of capital or the neoliberal university (mutual imagination). Such an imagination is to be embodied through life-giving actions and interventions and become concrete precisely in moments and spaces of solidarity, mutuality and prophecy.

\section{Acknowledgements Competing interests}

The author declares that he has no financial or personal relationships which may have inappropriately influenced him in writing this article.

\section{References}

Adams, P. \& Mylander, M., 1998, Gesundheit!, Healing Arts Press, Rochester, VT.

Ball, S.J., 2012, 'Performativity, commodification and commitment: An I-Spy guide to the neoliberal university', British Journal of Educational Studies, 60(1), 17-28. http://dx.doi.org/10.1080/00071005.2011.650940

Boff, L. \& Boff, C., 1986, Wat is theologie van de bevrijding? Averbode, Altiora.

Chatterton, P., Hodkinson, S. \& Pickerill, J., 2010, 'Beyond scholar activism: Making strategic interventions inside and outside the neoliberal university', ACME: An International E-Journal for Critical Geographies 9(2), 245-275.

Cone, J., 2001, ' "Let suffering speak": The vocation of a black intellectual', in G. Yancy (ed.), Cornel West. A critical reader, pp. 105-114, Blackwell Publishers, Oxford.

Cox, H., 1988, The silencing of Leonardo Boff: The Vatican and the future of world Christianity, Meyer Stone Books, Oak Park, IL.

Davey, A., 2008, 'Better place: Performing the urbanisms of hope', International Journa of Public Theology 2(1), 27-46. http://dx.doi.org/10.1163/156973208X256439

De Beer, S., 2014, 'Reimagining the third sector and its engagement with higher education institutions and local neighbourhoods. From scarcity to sustainability', in M. Erasmus \& R. Albertyn (eds.), Knowledge as enablement: Engagement between higher education and the third sector in South Africa, pp. 119-141, African SUN MeDia, Stellenbosch.

Faculty of Humanities, University of Pretoria, 2013, 'Capital cities: Space, justice and belonging, Institutional Research Theme (IRT) proposal', 15 March 2013, approved by the University Executive in April 2013.

Faculty of Theology, University of Pretoria, 2015, Pathways out of homelessness: Tshwane Homeless Summit, posted 12 May 2015, viewed 15 May 2015, from http://www.up.ac.za/en/faculty-of-theology/news/post_2079167-pathways-outof-homelessness-tshwane-homeless-summit

Feast of the Clowns, 2014, viewed 02 June 2015, from http://www.feastoftheclowns. org.za

Giroux, H., 2013, 'Public intellectuals against the Neoliberal University', in Truthout, 29 Oct 2013, viewed 05 May 2015, from http://www.truth-out.org/opinion/ item/19654-public-intellectuals-against-the-neoliberal-university\#

Graham, E., 2011, 'On finding ourselves: Theology, place and human flourishing', in M. Highton, J. Law \& C. Rowland (eds.), Theology and human flourishing: Essays in honour of Timothy J. Gorringe, pp. 265-279, Cascade Books, Eugene, OR.

Graham, E. \& Lowe, S., 2009, What makes a good city? Public theology and the urban church, Darton, Longman \& Todd Ltd., London. 
Gutierrez, G., 1988, A theology of liberation: History, politics, and salvation, Orbis Books, Maryknoll, NY.

Harvey, D., 1978, 'The urban process under capitalism: A framework for analysis', International Journal of Urban and Regional Research 2(104), 101-131, http:// dx.doi.org/10.1111/j.1468-2427.1978.tb00738.x

Kairos Southern Africa, 2011, 'Theological and ethical reflections on the 2012 Centenary celebrations of the African National Congress', conference of Kairos South Africa, 28 December 2011

Koopman, N., 2015, 'Human dignity, human rights and socio-economic exclusion?', in W. Gräb \& L. Charbonnier (eds.), Religion and human rights: Global challenges from intercultural perspectives, pp. 131-148, Walter de Gruyter, GmbH \& Co KG, Munich.

Kumar, K., 1997, From post-industrial to post-modern society, Blackwell, New York, Oxford.

Landman, C., 1996, 'Johan Heyns and the Class of '51 - prolegomena to a story of people who got hurt', Skrif en Kerk 17(2), 347-358. http://dx.doi.org/ 10.4102/ ve.v17i2.522

Lefebvre, H., 1996, Writings on cities, transl. and introduced by E. Kotman \& E. Labas, Blackwell, Oxford.

Lewin, H., 1987, A community of clowns: Testimonies of people in urban rural mission, WCC Publications, Geneva.

Messer, D.E., 1989, Contemporary images of Christian ministry, Abingdon Press, Nashville, TN.

Methula, D.W., 2014, 'Engaging in the struggle for economic justice on the streets of the City of Tshwane', Missionalia 42(1-2), 107-119.
Muers, R., 2011, 'Being planted: Prophetic visions of human sustainability', in M. Highton, J. Law \& C. Rowland (eds.), Theology and human flourishing: Essays in honour of Timothy J. Gorringe, pp. 265-279, Cascade Books, Eugene, OR.

Shamir, R, 2008, 'The age of responsibilitization: On market-embedded morality', Economy and Society, 37(1), 1-19. http://dx.doi.org/10.1080/ 03085140701760833

Slaughter, S. \& Rhoades, G., 2000, 'The Neo-Liberal University', New Labor Forum, Spring/Summer, 73-79.

Soja, E., 2000, Postmetropolis: Critical studies of cities and regions, Wiley, Hoboken, NJ.

Terreblanche, S., 2014, Verdeelde land. Hoe die Oorgang Suid-Afrika faal, Tafelberg, Kaapstad.

University of Pretoria Capital Cities Un-shack-led, 2014, 'Biennial Consultation on Urban Ministry', viewed 15 May 2015, from https://www.facebook.com/ events/361297717345140.

Vally, R., 2015, 'Programme Director, Day 1 of the Tshwane Homeless Summit, Pretoria', Ditsong Museum, Pretoria, 25 May 2015.

Vellem, V., 2013, 'A critical black analysis of the church's role in the post-apartheid struggle for socio-economic justice', Studia Historiae Ecclesiasticae XXXIX (2), 1-23.

West, C., 1988, Prophetic fragments, E. William Eerdmans Publishing Company, Grand Rapids, MI.

West, C., 1999, The Cornel West reader, Basic Civitas Books, New York, NY.

West, C., 2014, 'Black Prophetic Fire, Talk by Cornel West about his book Black Prophetic Fire', 9 October 2014, Town Hall Seattle, Seattle, WA.

Yancy, G. (ed.), 2001, Cornel West. A critical reader, Blackwell Publishers, Oxford 